\title{
Current status and breeding distribution of Red-legged Cormorant Phalacrocorax gaimardi along the Chilean coast
}

\author{
ESTEBAN FRERE, PATRICIA GANDINI, JORGE RUIZ and \\ YERKO A. VILINA
}

\begin{abstract}
Summary
Red-legged Cormorant Phalacrocorax gaimardi, considered Near Threatened, is one of the most conspicuous seabirds on the south Pacific coast, although its current status is unknown. During spring and summer of 1998, 1999 and 2000 we surveyed Red-legged Cormorants along the Chilean coast. Survey portions of the coast were chosen based on published information, and discussions with local people. Nesting sites were distributed from Arica $\left(18^{\circ} 30^{\prime} \mathrm{S}\right)$ to the Peninsula de Taitao $\left(46^{\circ} 25^{\prime} \mathrm{S}\right)$. We found 40 breeding areas with at least 54 colonies, ranging from two to 964 nests. Colony size (as number of breeding birds) was larger in the south than in the north. Isolated pairs or small colonies were found in the northern and central part of Chile. The southern coast ( $X^{\text {th }}$ Region) held most colonies, including the largest one with approximately 1,ooo breeding pairs, suggesting it is a critical area for the species. We estimated the Red-legged Cormorant population in Chile to be between 5,018 and 5,218 breeding pairs. The $X^{\text {th }}$ Region holds approximately $80 \%$ of the whole Chilean population. Factors affecting the breeding distribution of this bird in Chile include coastal development, nesting habitat availability and the occurrence of El Niño (ENSO) events. Human consumption may be important locally, mainly in the south. Chile holds more than $70 \%$ of the world breeding population, estimated at fewer than 15,000 individuals. The Peruvian population has declined during recent decades, and the Argentinean population seems to be small and stable. Thus the Chilean coast, particularly the $\mathrm{X}^{\text {th }}$ Region, is a critical area for the conservation of this species.
\end{abstract}

\section{Introduction}

Red-legged cormorant Phalacrocorax gaimardi breeds from northern Peru to South Chile along the Pacific coast and along a short portion of the Argentinean South Atlantic coast in Santa Cruz (Harrison 1985, Gandini and Frere 1995, Zavalaga et al. 2002). Its current status in Argentina and Peru has been assessed previously (Gandini and Frere 1995, Zavalaga et al. 2002). The breeding population appears much lower than was thought, and the last El Niño Southern Oscillation event (ENSO) had an important effect on abundance, particularly along the Peruvian coast (Zavalaga et al. 2002). ENSO is responsible for changes in breeding and behavioural strategies of many seabird species along the Pacific coast, and hence their abundance and distribution (Tovar and Cabrera 1985, Boersma 1998, Jahncke 1998, Paredes and Zavalaga 1998, Culik et al. 2000). The coast of Peru and north and central Chile are influenced by ENSO events, with potential effects on the breeding distribution of Red-legged Cormorant. 
Red-legged Cormorant is a common seabird in Chile but is one of the least known. Since Murphy (1936), only Schlatter (1984) and Schlatter and Simeone (1999) have mentioned its status in Chile, where opinions differ on its general distribution. Araya and Millie (1993) and Johnsgard (1993) stated that it ranges from Arica to Tierra del Fuego ( $\left.54^{\circ} \mathrm{S}\right)$, whilst Del Hoyo et al. (1994) stated that it extends only to the south of Chiloé $\left(45^{\circ} \mathrm{S}\right)$. Considered "vulnerable" in Chile and Argentina (Collar et al. 1994, Gandini and Frere 1995) it is classified as Near Threatened by BirdLife International (2000). We aimed to determine the size and distribution of current breeding populations of Red-legged Cormorant in Chile, and the main threats to the species. We make the first presentation of its world population status.

\section{Methods}

During the spring and summer of 1998, 1999 and 2000 we carried out surveys along the Chilean coast to record breeding sites, number and contents of nests and nest characteristics of Red-legged Cormorants. We chose portions of the coast to be surveyed using previously published information, and by talking with local people. Portions of the coast with flat areas, on slopes or on cliffs covered by sand, sandstone or other loose soil were not surveyed because the species is an obligate cliff nester; Zavalaga et al. (2002) never found nests in this type of habitat. We recorded the geographic location of the colony with a GPS (Garmin III plus) and recorded other seabird species. Red-legged Cormorant exhibits high reproductive asynchrony both within and among colonies, but most of the breeding adults stay at the colonies all year round (Gandini and Frere 1995, Frere unpubl. data). We considered a nest to be active when it had at least an adult, an egg or a chick in it. The number of active nests was estimated by direct counts made with binoculars $(10 \times 50)$ or telescope $(\times 40)$ from boats in those colonies that were located on islands or cliffs, from the ground in some cases (headlands) and from the air where the sites were inaccessible (West coast of Isla Chiloé). For the aerial survey two observers carried out counts from a Cessna 172, flying at an altitude of $60-90 \mathrm{~m}$. We photographed each colony with a $35-\mathrm{mm}$ camera with $80-200 \mathrm{~mm}$ lens, and estimated their size by counting birds in the photographs. Any incubating cormorant or pair associated with a nest was considered a breeding pair.

\section{Results}

Nesting sites were distributed along the Chilean coast from Arica ( $18^{\circ} 30^{\prime} \mathrm{S}$ ), in the $\mathrm{I}^{\text {st }}$ Region, to the Peninsula de Taitao $\left(46^{\circ} 25^{\prime} \mathrm{S}\right)$, in the XI $\mathrm{I}^{\text {th }}$ Region (Table 1 ). No nesting sites were found in the south of the XI ${ }^{\text {th }}$ Region or in the XII ${ }^{\text {th }}$ Region (Figure 1). We found nests only on high rocky cliffs, seacaves or rocky islets located near to the shore. Nests consisted of fronds of seaweed, feathers and guano. Plastic garbage was also frequently observed in the nest.

In northern and central areas of the Chilean coastline, birds were found breeding in small colonies ( $<10$ nests) or in isolated pairs (Figure 2). From Arica to Iquique $\left(20^{\circ} 20^{\prime} \mathrm{S}\right)$, most nests were located on high vertical rocky cliffs up to 
Table 1. Location and size (no. of active nests) of breeding sites of Red-legged Cormorant in Chile.

\begin{tabular}{|c|c|c|c|}
\hline & Breeding sites & Latitude & No. of nests ${ }^{a}$ \\
\hline & Northern zone & & \\
\hline 1 & Arica - Iquique & $18^{\circ} 30^{\prime} \mathrm{S}-20^{\circ} 20^{\prime} \mathrm{S}$ & $50-100$ \\
\hline 2 & Punta Sarmenia - Bahía Quintero - Isla Mantagua & $20^{\circ} 27^{\prime} \mathrm{S}-21^{\circ} 25^{\prime} \mathrm{S}$ & $71-73$ \\
\hline 3 & Isla Malpaso - Bahía Mejillones - Punta Angamos & $22^{\circ} 10^{\prime} \mathrm{S}-23^{\circ} \mathrm{OI}^{\prime} \mathrm{S}$ & $64-84$ \\
\hline \multirow[t]{2}{*}{4} & Parque Nacional Pan de Azucar & $26^{\circ} \mathrm{Oo} \mathrm{S}$ & $8-14$ \\
\hline & Central zone & & \\
\hline 5 & Isla Chañaral — Punta Chungungo & $29^{\circ} \mathrm{OO}^{\prime} \mathrm{S}-29^{\circ} 24^{\prime} \mathrm{S}$ & $53-66$ \\
\hline 6 & Parque Fray Jorge - Bahía Vilos & $30^{\circ} 40^{\prime} \mathrm{S}-31^{\circ} 50^{\prime} \mathrm{S}$ & 10 \\
\hline 7 & Islote Concon & $32^{\circ} 56^{\prime} \mathrm{S}$ & $12-15$ \\
\hline 8 & Peñon Cabras — Isla Chicaumilla & $33^{\circ} 12^{\prime} \mathrm{S}-33^{\circ} 15^{\prime} \mathrm{S}$ & 150 \\
\hline \multirow[t]{2}{*}{9} & Faro Carranza & $36^{\circ} \mathrm{Oo} \mathrm{S}$ & 2 \\
\hline & Southern zone & & \\
\hline 10 & Tirua - Quidicio - Isla Mocha & $38^{\circ} 20^{\prime} \mathrm{S}-38^{\circ} 22^{\prime} \mathrm{S}$ & $100-115$ \\
\hline 11 & Punta Ronca (Queule) & $39^{\circ} 23^{\prime} \mathrm{S}$ & 964 \\
\hline 12 & Isla Maiquiyahue & $39^{\circ} 27^{\prime} \mathrm{S}$ & 208 \\
\hline 13 & Costa Maiquiyahue & $39^{\circ} 28^{\prime} \mathrm{S}$ & 117 \\
\hline 14 & Chanchán & $39^{\circ} 34^{\prime} \mathrm{S}$ & 61 \\
\hline 15 & Pilolcura & $39^{\circ} 40^{\prime} \mathrm{S}$ & 104 \\
\hline 16 & Colonia Curiñanco & $39^{\circ} 41^{\prime} \mathrm{S}$ & 93 \\
\hline 17 & Curiñanco & $39^{\circ} 42^{\prime} \mathrm{S}$ & 38 \\
\hline 18 & Morro Gonzalo & $39^{\circ} 50^{\prime} \mathrm{S}$ & $36-40$ \\
\hline 19 & Roca Covadonga - Punta Llesquehue & $40^{\circ} 26^{\prime} \mathrm{S}-40^{\circ} 53^{\prime} \mathrm{S}$ & $?$ \\
\hline 20 & Cerro Amortajado & $41^{\circ} 39^{\prime} \mathrm{S}$ & 691 \\
\hline 21 & Islotes Farallones & $41^{\circ} 41^{\prime} S$ & $120-140$ \\
\hline 22 & Península Chocoy & $41^{\circ} 45^{\prime} \mathrm{S}$ & 398 \\
\hline 23 & Isla Doña Sebastiana & $41^{\circ} 45^{\prime} \mathrm{S}$ & 703 \\
\hline 24 & Punta Quillagua & $41^{\circ} 46^{\prime} \mathrm{S}$ & 2 \\
\hline 25 & Punta Corona & $41^{\circ} 47^{\prime} \mathrm{S}$ & 250 \\
\hline 26 & Península Guabun & $41^{\circ} 48^{\prime} \mathrm{S}$ & $10-12$ \\
\hline 27 & Islotes Piñihuil & $41^{\circ} 56^{\prime} \mathrm{S}$ & $27-30$ \\
\hline 28 & Islotes al Sur de Piñihuil & $41^{\circ} 57^{\prime} \mathrm{S}$ & $28-30$ \\
\hline 29 & Punta Pirulil & $42^{\circ} 44^{\prime} \mathrm{S}$ & 150 \\
\hline 30 & Punta Bonita Norte & $42^{\circ} 46^{\prime} \mathrm{S}$ & 80 \\
\hline 31 & Punta Bonita Centro & $42^{\circ} 47^{\prime} \mathrm{S}$ & 70 \\
\hline 32 & Punta Bonita Sur & $42^{\circ} 48^{\prime} \mathrm{S}$ & 10 \\
\hline 33 & Punta Checo & $42^{\circ} 49^{\prime} \mathrm{S}$ & 20 \\
\hline 34 & Punta Ayao & $42^{\circ} 54^{\prime} \mathrm{S}$ & 30 \\
\hline 35 & Punta Tablaruca & $42^{\circ} 56^{\prime} \mathrm{S}$ & 50 \\
\hline 36 & Punta Chaiguaco & $43^{\circ} \mathrm{OO}^{\prime} \mathrm{S}$ & 145 \\
\hline 37 & Punta Zorra & $43^{\circ} \mathrm{Og}^{\prime} \mathrm{S}$ & 3 \\
\hline 38 & Carrera de Cuchi & $45^{\circ} 20^{\prime} \mathrm{S}$ & 10 \\
\hline 39 & Isla Reimapu & $45^{\circ} 47^{\prime} \mathrm{S}$ & $30-40$ \\
\hline \multirow[t]{2}{*}{40} & Punta Elefante & $46^{\circ} 25^{\prime} \mathrm{S}$ & $50-100$ \\
\hline & TOTAL & & $5,018-5,218$ \\
\hline
\end{tabular}

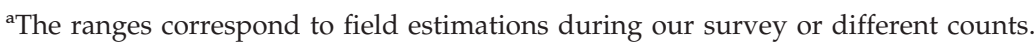

$200 \mathrm{~m}$ high, whereas from Iquique until $30^{\circ}$ of latitude nests were on islets or small headlands. In the south, colony sizes were bigger than in the north (Figure 2). For the Chilean breeding population, the median size of the colonies was 15 nests but highly variable (range 1-964 nests; Figure 2), being intermediate between the size in Peru (median 5 nests) and Argentina (median 30 nests). 


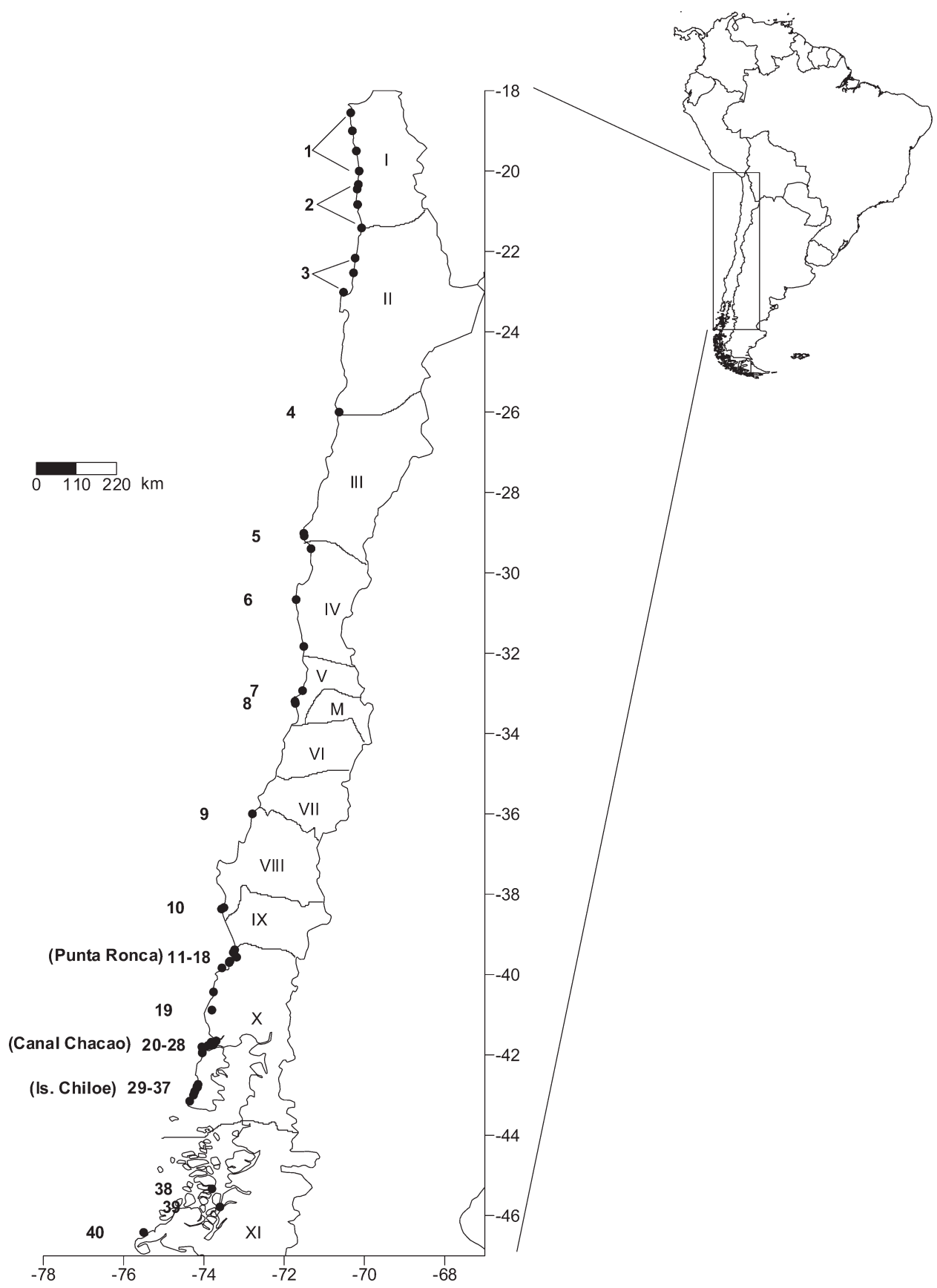

Figure 1. Breeding distribution of Red-legged Cormorant along the coast of Chile. Regions are labelled with roman numerals. " $\mathrm{M}$ " indicates the Metropolitan Region.

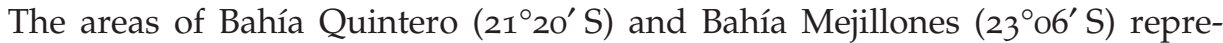
sent the largest breeding sites of this species in northern Chile, with almost 150 pairs breeding in different nesting colonies inside the bays (Table 1). Bahía 


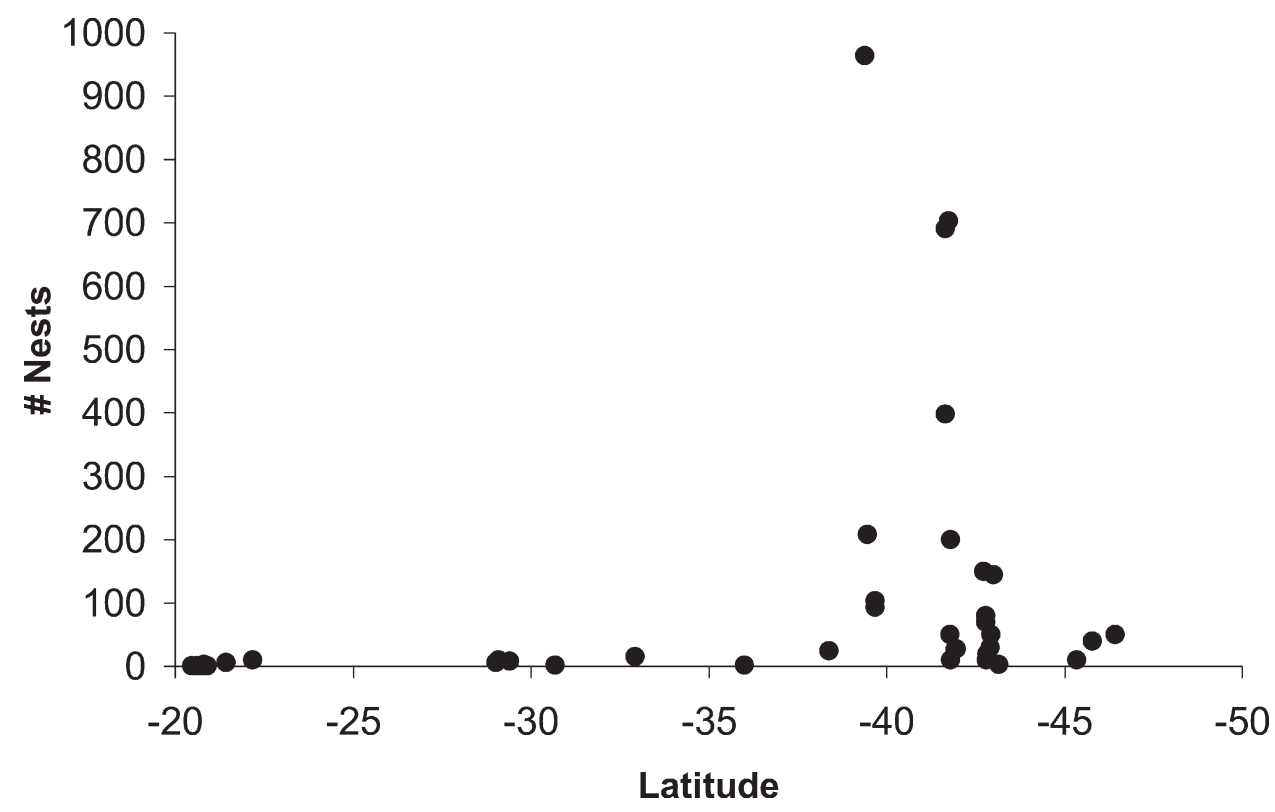

Figure 2. Size of Red-legged Cormorant colonies and latitude along the Chilean coast.

Mejillones was also identified as an important feeding area. We saw between 100 and 150 individuals (adults and juveniles) feeding at the end of October, and 500 were feeding in the bay during July (Lorenzo Demetrio pers. comm.). At this bay, Red-legged Cormorants were kleptoparasitized by Garumas Gulls Larus modestus, and potential predators such as Black-crowned Night-Herons Nycticorax nycticorax and Band-tailed Gulls Larus belcheri were seen near to the colonies.

Few cormorants were found along the central part of the Chilean coast (between IV $^{\text {th }}$ and VIII ${ }^{\text {th }}$ Regions) (Figure 1 ). This is probably due to the lack of rocky cliffs and the presence of large coastal cities such as La Serena, Valparaiso, San Antonio and Concepción. The segment between Chañaral and Punta Chungungo (Table 1 ), one of the most important nesting areas, is far away from big cities and the roads are far from the coast. The number of breeding pairs per colony increased rapidly south of $38^{\circ} \mathrm{S}$ (Figure 2), with the highest number of breeding colonies between $41^{\circ} 30^{\prime} \mathrm{S}$ and $43^{\circ} \mathrm{S}$ (Canal Chacao and Isla Chiloé; Figure 1). The southern region had the largest colony. Punta Ronca had almost 1,00o breeding pairs (Table 1). We saw up to 400 non-breeding adults at Punta Ronca and Canal Chacao resting on rocky cliffs and coastal rocks during the breeding period (October-January). We also saw hundreds of non-breeding adult Chilean Pelicans Pelecanus thagus, Peruvian Boobies Sula variegata and Guanay Cormorants Phalacrocorax bougainvillii.

Red-legged Cormorant distribution in Chile goes from Arica to Peninsula de Taitao, with 40 breeding areas (Table 1) containing at least 54 colonies. The northernmost site was close to Arica and the southernmost colony was found at the Peninsula de Taitao (Punta Elefante), within the National Park Laguna San Rafael (Table 1). 
We estimated the Red-legged Cormorant population in Chile to be between 5,018 and 5,218 breeding pairs (Table 1 ), only the $X^{\text {th }}$ Region holding more than 4,00o breeding pairs.

\section{Discussion}

This study presents the first evaluation of the breeding distribution and population size of Red-legged Cormorants in Chile. The species is distributed along $3,000 \mathrm{~km}$ of Chilean coast, from Arica to Peninsula de Taitao. The southern limit of the breeding distribution was at Punta Elefante $\left(46^{\circ} 25^{\prime} \mathrm{S} 75^{\circ} 30^{\prime} \mathrm{W}\right)$, further south than the southern limits reported by Harrison (1985) and Johnsgard (1993).

Red-legged Cormorants were found breeding in isolated nests or in small colonies in the north and central coast of Chile, consistent with the description by Murphy (1936). However in the southern area most of the colonies held hundreds of nests. Colonies were larger and had more breeding sites in the south. Likewise Zavalaga et al. (2002) found larger colonies in the south in Peru, where the authors attribute that pattern to the availability of nesting habitat along the coast.

In Chile factors such as coastal development, nesting habitat availability and the occurrence of El Niño Southern Oscillation (ENSO) events might be affecting the pattern of the species' breeding distribution. The ENSO affects seabird populations in Peru, including Red-legged Cormorant (Tovar and Cabrera 1985, Zavalaga et al. 2002). In Chile, Humboldt Penguins Spheniscus humboldti migrated to the south during the strong 1997-1998 ENSO (Culik et al. 2000), and could have occupied new breeding areas to the south as a consequence of strong ENSO events (Araya and Todd 1987). During recent decades, ENSO events have been stronger and more frequent (Boersma 1998, Jaksic 2001), and were particularly strong during 1982-1983, 1991-1992 and 1997-1998 (Barber and Chavez 1983, Boersma 1998, McPhaden 1999, Wang and Weisberg 2000). Interestingly, during this period many seabird species such as Chilean Pelican, Peruvian Booby and Guanay Cormorant expanded their range to the south (R. Schlatter pers. comm.; pers. obs.). Although Red-legged Cormorants have been present in the $X^{\text {th }}$ Region for the last 5,000 years (Simeone and Navarro 2002), the highly productive coastal waters of the $X^{\text {th }}$ Region, particularly during the ENSO events, may function as a "refuge" for the species. Consistent with this is the fact that the bigger colonies are in the south, and colonies are larger than when Murphy (1936) described them.

The lack of nesting habitats and movement from northern areas may explain the high concentrations of non-breeding adults during the breeding season at Punta Ronca and Canal Chacao. Moreover that portion of coast may be excellent foraging habitat for this species (Moreno 2001), the coast having a longitudinal extent of $560 \mathrm{~km}, 408 \mathrm{~km}$ of which is rocky intertidal coast — ideal foraging habitat for the species (Frere et al. 2002).

The $X^{\text {th }}$ Region in Chile appears to be a key area for the conservation of the species, a single colony at Punta Ronca holding as many breeding pairs as the whole Argentine Red-legged Cormorant population (Gandini and Frere 1995) and the Peruvian one (Zavalaga et al. 2002). 
Along the Chilean coast, all the breeding sites were located on the external coast of the Pacific Ocean, where the continental shelf has a mean width of $6.5 \mathrm{~km}$ (Gallardo 1984), except for Carrera de Cuchi and Isla Reimapu located where the continental shelf is not present. The distribution pattern for this species is consistent with its diving and foraging behaviour. Red-legged Cormorants are inshore feeders (less than $3 \mathrm{~km}$ from the colony) and forage in shallow waters $(<15 \mathrm{~m})$ on benthic fish and invertebrates (Frere et al. 2002).

Red-legged Cormorants in Chile are threatened by diverse human activities related to coastal development. Fishermen indicate that adults are eaten and people also collect eggs and chicks. Fishermen do not apparently take the birds in the III' ${ }^{\text {th }}$, IV th and $\mathrm{V}^{\text {th }}$ Regions as much as they did several decades ago (Frere unpubl. data, Schlatter 1984). However, in the $X^{\text {th }}$ Region they seem to be commonly hunted by fishermen as well as by seafood- and algae-gatherers. In this Region, of 20 fishermen personally interviewed, four reported that they hunted Red-legged Cormorants for consumption or for use as bait for fishing rock crabs Homalaspis plana (Frere unpubl. data). Whilst bird-hunting occurs infrequently, a group of fishermen from Carelmapu $\left(41^{\circ} 44^{\prime} \mathrm{S} 73^{\circ} 43^{\prime} \mathrm{W}\right)$ captured around 300 Red-legged Cormorants in a single hunting trip (C. Lemus pers. comm.). Hunting appears to be occasional but it may threaten local colonies because of the high number of birds killed during each hunting event.

Incidental capture in artisanal fishing nets has been reported in central Chile (Simeone et al. 1999), but is unlikely to be an important cause of mortality because most fisheries are for shellfish. However, coastal habitats such as rocky intertidals and shallow rocky bottoms are important feeding areas for this diving species (Frere et al. 2002), and in Chile these ecosystems are subject to a high human impact as the result of the collection of invertebrates and macroalgae by artisanal fishermen and gatherers (Fernandez et al. 2000). Currently more than 22,00o divers and food-gatherers are exploiting benthic invertebrates, mainly in the $\mathrm{IV}^{\text {th }}, \mathrm{V}^{\text {th }}, \mathrm{VIII}{ }^{\text {th }}$ and $\mathrm{X}^{\text {th }}$ Regions (Moreno 2000). This is likely to have an important influence on patterns of abundance and diversity of the communities on rocky intertidal shores (Moreno 2001), making this activity a potential threat for the species.

The Peruvian population declined after the last El Niño and was estimated to be 1,800 breeding adults (Zavalaga et al. 2002). The Argentinean population seems to be stable but with low numbers (2,200 breeding adults; Gandini and Frere 1995). The results of this work highlight that the Chilean coast, with approximately 5,000 breeding pairs, and especially the $X^{\text {th }}$ Region, are critical for the protection of this threatened species. Chile holds more than $70 \%$ of the world population of Red-legged Cormorant, which is considered to be fewer than 15,000 individuals.

Chile is discussing the creation of a network of Marine Protected Areas (MPAs) along its coast (Fernandez et al. 2000). The conservation needs of Red-legged Cormorant and other seabird species should be considered in the selection of target areas and in the designation of new MPAs.

\section{Acknowledgements}

The Wildlife Conservation Society funded this work. We are grateful to Alejandro Simeone, Dr Roberto Schlatter, Daniela Guicking, Andreas von Meyer, 
Mariano Bernal, Luis Espinosa, Jorge Valenzuela, Flavio Quintana, Carlos Appel and many Chilean friends along the coast, who contributed valuable information on the size and locations of breeding colonies or helped with the fieldwork. Also we are grateful to Dee Boersma, Pablo Yorio, Eric Gilman, Alejandro Simeone, Seb Buckton and two anonymous reviewers for their valuable comments on the manuscript.

\section{References}

Araya, B. and Millie, G. (1993) Guía De Campo De Las Aves de Chile. Santiago, Chile: Editorial Universitaria.

Araya, B. and Todd, F. (1987) Status of the Humboldt penguin in Chile following the 1982-83 El Niño. Pp. 125-136 in Proceedings of the Jean Delacour/IFBC Symposium, Los Angeles, California.

Barber, R. T. and Chavez, F. P. (1983) Biological consequences of El Niño. Science 222: 1203-1210.

BirdLife International (2000) Threatened birds of the world. Barcelona and Cambridge: Lynx Edicians and BirdLife International.

Boersma, D. P. (1998) Populations trends of the Galapagos Penguin: impacts of El Niño and La Niña. Condor 100: 245-253.

Collar, N. J., Crosby, M. J. and Stattersfield, A. J. (1994) Birds to watch 2. The world-list of threatened birds. Cambridge, U.K.: BirdLife International.

Culik, B., Hennicke, J. and Martin, T. (2000) Humboldt Penguins outmanoeuvring El Niño. J. Exp. Biol. 203: 2311-2322.

Del Hoyo, J., Elliot, A. and Sargatal, J. (1994) Handbook of the birds of the World. Vol. 2. Barcelona, Spain: Lynx Editions.

Fernandez, M., Jaramillo, E., Marquet, P., Moreno, C., Navarrete, S., Ojeda, P., Valdovinos, C. and Vasquez, J. (2000) Diversity, dynamics and biogeography of Chilean benthic nearshore ecosystems: an overview and guidelines for conservation. Rev. Chil. Hist. Nat. 73: 797-830.

Frere, E., Quintana, F. and Gandini, P. (2002) Diving behavior of the Red-legged Cormorant in southeastern Patagonia, Argentina. Condor 104: 440-444.

Gallardo, V. A. (1984) Revision actualizada a 1983 de la contaminacion marina provenientes de fuentes terrestres en la region del Pacifico sudeste (Colombia, Chile, Ecuador, Panama y Peru). Rev. Com. Perma. Pac. Sur 14: 19-173.

Gandini, P. and Frere, E. (1995) Distribución, abundancia y ciclo reproductivo del Comorán gris (Phalacrocorax gaimardi ) en la costa patagónica, Argentina. Hornero 14: 57-60.

Harrison, P. (1985) Seabirds. An identification guide. London: Christopher Holm.

Jahncke, J. (1998) Las poblaciones de aves guaneras y sus relaciones con la disponibilidad de anchoveta y la ocurrencia de eventos El Niño en el mar peruano. Bol. Inst. Mar Perú 17: 1-13.

Jaksic, F. (2001) Ecological effects of El Niño in terrestrial ecosystems of western South America. Ecography 24: 241-250.

Johnsgard, P. (1993) Cormorants, darters and pelicans of the world. Washington, DC: Smithsonian Institution Press.

McPhaden, M. J. (1999) Genesis and evolution of the 1997-98 El Niño. Science 283: 950-954.

Moreno, C. A. (2000) Areas marinas y borde costero. Pp. 245-286 in P. F. Brzovic and M. Romaggi, eds. Estado del medio ambiente en Chile. Santiago: Universidad de Chile.

Moreno, C. A. (2001) Community patterns generated by human harvesting on Chilean shores: a review. Aquat. Conserv. Mar. Freshwat. Ecosyst. 11: 19-30.

Murphy, R. C. (1936) Oceanic birds of South America. Vol. 2. New York: Macmillan. 
Paredes, R. and Zavalaga, C. B. (1998) Overview of the effects of El Niño 1997-98 on Humboldt penguins and others seabirds at Punta San Juan, Peru. Peng. Conserv. 11: 5-7.

Schlatter, R. P. (1984) The status and conservation of seabirds in Chile. Pp. 261-269 in J. P. Croxall, P. G. H. Evans and R. W. Schreiber, eds. Status and conservation of the world's seabirds. Cambridge, U.K.: International Council for Bird Preservation.

Schlatter, R. P. and Simeone, A. (1999) Estado del conocimiento y conservación de las aves en mares chilenos. Estud. Oceanol. 18: 25-33.

Simeone, A. and Navarro, X. (2002) Human exploitation of seabirds in coastal southern Chile during mid-Holocene. Rev. Chil. Hist. Nat. 75: 423-431.

Simeone, A., Bernal, M. and Meza, J. (1999) Incidental mortality of Humboldt penguins (Spheniscus humboldti) in gill nets, Central Chile. Mar. Orn. 27: 157-161.

Tovar, H. and Cabrera, D. (1985) Las aves guaneras y el fenómeno de El Niño. Pp. 181-186 in W. E. Arntz, A. Landa and J. Tarazona, eds. El Niño su impacto en la fauna marina. Boletín Instituto del Mar del Peru. Volumen extraordinario. Callao: IMARPE.

Wang, C. and Weisberg, R.H. (2000) The 1997-98 El Niño evolution relative to previous El Niño events. J. Climate 13: 488-501.

Zavalaga, C. B., Frere, E. and Gandini, P. (2002) Status of the Red-legged Cormorant in Peru: What factors affect distribution and numbers? Waterbirds 25: 8-15.

\section{ESTEBAN FRERE* and PATRICIA GANDINI}

Centro de Investigaciones Puerto Deseado, Universidad Nacional de la Patagonia Austral, CONICET, and Wildlife Conservation Society. Lotufo S/N (905o) Puerto Deseado, Santa Cruz, Argentina. E-mail: estebanfrere@yahoo.com.ar

\section{JORGE RUIZ}

Hualamo, Puelche 2454, Barrio el Estanque, Valdivia. X Region, Chile.

YERKO A. VILINA

Escuela de Medicina Veterinaria, Universidad Santo Tomás, Ejercito 146, Santiago de Chile, Chile.

${ }^{*}$ Corresponding author

Received 25 September 2002; revision accepted 2 December 2003 